\title{
CALCIFIED LIGAMENTA FLAVA IN A PATIENT WITH COFFIN-LOWRY SYNDROME: BIOCHEMICAL ANALYSIS OF GLYCOSAMINOGLYCANS
}

\author{
Kiyoshi MiYazaki, ${ }^{1}$ Tsutomu Yamanaka, ${ }^{1}$ Yoshito Ishida, ${ }^{2}$ \\ and Atsuhiko OoHIRA ${ }^{3}$ \\ Departments of ${ }^{1}$ Pediatrics and ${ }^{2}$ Orthopedic Surgery, Central Hospital, and \\ ${ }^{3}$ Department of Embryology, Institute for Developmental Research, \\ Aichi Prefectural Colony, Kasugai, Aichi 480-03, Japan
}

\begin{abstract}
Summary Glycosaminoglycans in calcified cervical ligamenta flava from a male patient with Coffin-Lowry syndrome were analyzed biochemically. Hexuronate content based on the tissue dry weight was 8-fold and 5 -fold concentrated in the calcified center as compared with the peripheral area and with age-matched, normal ligamenta flava, respectively. Twodimensional electrophoresis of glycosaminoglycan preparations on cellulose acetate film revealed that, although dermatan sulfate was the major glycosaminoglycan in the normal ligamenta flava, chondroitin sulfate was the predominant glycosaminoglycan in the pathological tissue. Relative amounts of chondroitin sulfate disaccharide units were determined after digestion of glycosaminoglycans with chondroitinase, and the ratio of chondroitin 6-sulfate to chondroitin 4-sulfate tended to decrease with the distance from the calcified center to the peripheral area. These observations suggest that an alteration in glycosaminoglycan metabolism may be a contributing factor in calcification of ligamenta flava in Coffin-Lowry syndrome.
\end{abstract}

Key Words calcification, Coffin-Lowry syndrome, connective tissue, glycosaminoglycans, ligamentum flavum

\section{INTRODUCTION}

Coffin-Lowry syndrome is a relatively rare genetic disorder characterized by severe mental retardation, short stature, craniofacial anomalies, hand findings, and several skeletal abnormalities (Coffin et al., 1966; Lowry et al., 1971; Temtamy et al., 1975).

Temtamy et al. (1975) suggested that Coffin-Lowry syndrome is a heritable disorder of connective tissue from clinical observations as well as from histopath-

Received February 19, 1990; revised version received March 26, 1990; Accepted April 4, 1990 
ologic findings of skin. While some authors reported the abnormal proteodermatan sulfate metabolism in cultured skin fibroblasts (Beck et al., 1983) or the stored glycoprotein-like material in cultured cartilage cells (Gorlin et al., 1978), the primary defect of Coffin-Lowry syndrome is still unknown.

In this paper, we report a male adult patient with Coffin-Lowry syndrome whose cervical spinal canal was compressed by calcified ligamenta flava. Special attention was paid to biochemical analysis of glycosaminoglycans (GAGs) isolated from calcified ligamenta flava.

\section{MATERIALS AND METHODS}

The patient was 22-year-old Japanese man with full expressions of CoffinLowry syndrome. His neck was stiff and its motion was restricted in forward and backward directions. His gait was spastic and he had difficulty in walking. Deep tendon reflexes were exaggerated especially in legs and a Babinski sign was elicited. Roentgenological examinations of the cervical spine were carried out (Fig. 1) and they showed that both cervical (C1-2 to C7-T1) and lumbar (L2-3 to L4-5) ligamenta flava were calcified. We retrospectively evaluated cervical spine film examined when he was 14 years old, and this film already showed calcifications, though of a mild degree, of ligamenta flava. Computed tomography showed that the spinal canal, especially at the cervical spine level, was narrowed about to half when he was 22 years old. To remove the spinal canal compression, calcified ligamenta flava were resected surgically.
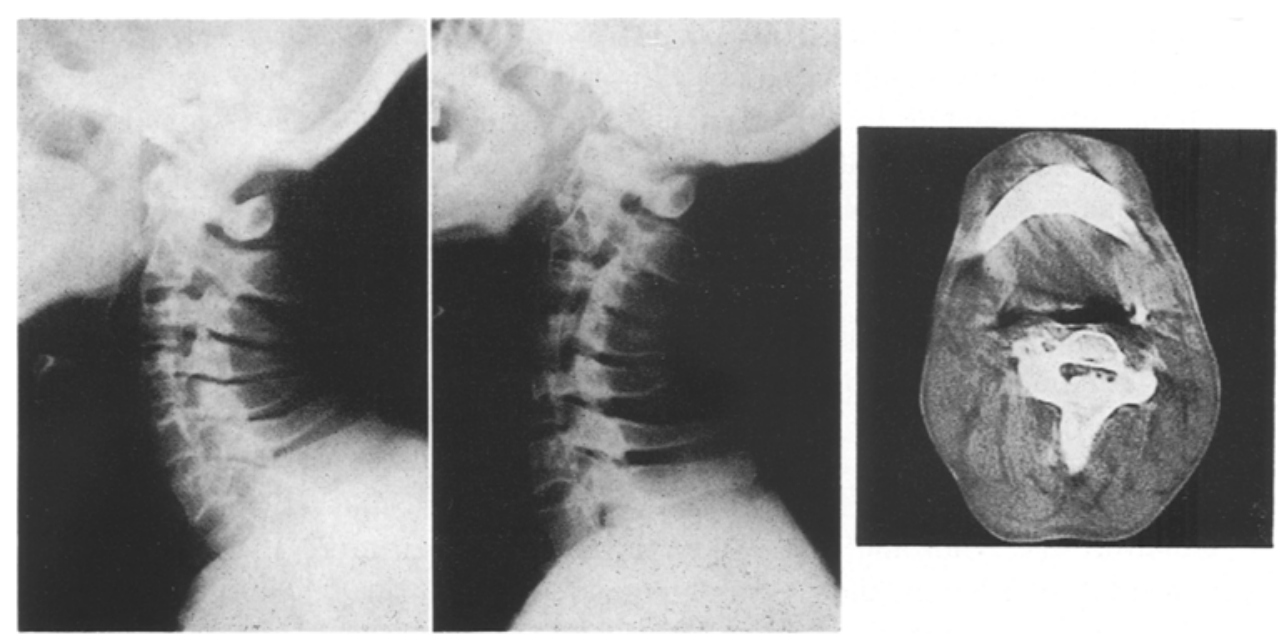

Fig. 1. Roentgenological examinations of the cervical spine. Left and middle: cervical lateral films, examined when he was 14 and 22 years old, respectively. They show multiple radiopaque nodular shadows which became more pronounced with age. Right: computed tomography of cervical spine shows oval-shaped calcified ligamentum flavum located in the posterior portion of the spinal canal which was markedly narrowed. 
Informed consent was obtained prior to this study. As controls, both normal ligamenta flava from a 25 -year-old female with idiopathic scoliosis and uncalcified ligamenta flava from a 14-year-old boy with Coffin-Lowry syndrome complicated by scoliosis were also analyzed. Excised material from calcified ligamenta flava was divided into three parts; calcified center, peripheral area which was adherent to dura, and transitional area between them. Each tissue was cut into small pieces and treated with cold acetone. The acetone-dried tissue segments $(100 \mathrm{mg})$ were decalcified with $5 \mathrm{ml}$ of $0.5 \mathrm{M}$ EDTA-50 mM Tris- $\mathrm{HCl}, \mathrm{pH} 7.5$, by stirring at room temperature. After 3 days, the residue was separated from EDTA solution by centrifugation, and subjected again to decalcification under the same conditions. After centrifugation, both EDTA solutions were combined and the final organic residue was dried and weighed.

GAGs were prepared separately both from the EDTA extract and from the residue as follows. The EDTA extract was dialyzed against distilled water at $4{ }^{\circ} \mathrm{C}$, and the dialysate was lyophilized. The dried material was dissolved in $1 \mathrm{ml}$ of $50 \mathrm{~mm}$ Tris- $\mathrm{HCl}, \mathrm{pH} 7.5$, containing about $1 \mathrm{mg}$ of pronase E (Kaken Seiyaku, Tokyo) and $3 \%$ ethanol, and incubated at $50^{\circ} \mathrm{C}$ overnight. GAGs were prepared from the pronase digest by the sequential treatments with $0.4 \mathrm{~N} \mathrm{NaOH}, 5 \%$ trichroloacetic acid, and precipitation with $70 \%$ ethanol containing $1 \%$ potassium acetate, as described previously (Oohira et al., 1986). The organic residue was digested with pronase $(\mathrm{ca} .1 \mathrm{mg} / \mathrm{ml})$ in $5 \mathrm{ml}$ of $0.1 \mathrm{M}$ EDTA-50 mM Tris- $\mathrm{HCl}, \mathrm{pH}$ 7.5 , at $50^{\circ} \mathrm{C}$ for $48 \mathrm{hr}$. Undigested material was incubated in $5 \mathrm{ml}$ of the fresh pronase solution at $50^{\circ} \mathrm{C}$ for another $24 \mathrm{hr}$. Under the conditions used, the organic residue was almost solubilized in the pronase-reaction buffer. After both pronasereaction buffers were combined, $2 \mathrm{ml}$ of $2 \mathrm{~N} \mathrm{NaOH}$ was added to the pronase digest. After $16 \mathrm{hr}$ at room temperature, the mixture was neutralized at $0^{\circ} \mathrm{C}$ with $1 \mathrm{ml}$ of $4 \mathrm{~N} \mathrm{HCl}$, and then $50 \%$ trichroloacetic acid was added to the solution to give a final concentration of $5 \%$. After standing at $0^{\circ} \mathrm{C}$ for $30 \mathrm{~min}$, the solution was centrifuged at $15,000 \times g$ for $20 \mathrm{~min}$. The supernatant fluid, after neutralization with $2 \mathrm{~N} \mathrm{NaOH}$, was dialyzed against distilled water at $4^{\circ} \mathrm{C}$. GAGs were precipitated from the dialysate by adding 3 volumes of $95 \%$ ethanol containing $1.3 \%$ potassium acetate.

Excised materials from normal ligamenta flava and uncalcified ligamenta flava were treated separately with cold acetone overnight. The acetone-dried tissue was digested with pronase $(\mathrm{ca} .1 \mathrm{mg} / \mathrm{ml})$ in 50 volumes $(\mathrm{v} / \mathrm{w})$ of the pronase solution for $48 \mathrm{hr}$, and GAGs were prepared by the sequential treatments of the pronasedigest with $0.4 \mathrm{~N} \mathrm{NaOH}, 5 \%$ trichroloacetic acid, and precipitation with $70 \%$ ethanol containing $1 \%$ potassium acetate, as described above. Hexuronate content in the crude GAG preparation was determined by the method of Bitter and Muir (1962).

For the characterization, GAG preparations (20 nmol of hexuronate) were separated by two-dimensional electrophoresis (2-D-E) on cellulose acetate by the method of Hata and Nagai (1972). 
The relative amounts of chondroitin sulfate disaccharide units formed by the action of chondroitinase-ABC or chondroitinase-AC II (Seikagaku Kogyo, Tokyo) upon GAG preparations were determined by the method of Saito et al. (1968).

\section{RESULTS}

Table 1 shows the characterization of ligamenta flava from three subjects. Decalcification with EDTA solution resulted in more than $50 \%$ reduction of the tissue dry weight in each pathological tissue. Some parts (about $20 \%$ of total) of hexuronate-containing material was solubilized with EDTA solution. Total hexuronate contents, based on the tissue dry weight, tended to increase successively from peripheral area to calcified center. Hexuronate content of calcified center was about 8-fold concentrated as compared with the peripheral area, and about 5 -fold concentrated as compared with the normal, age-matched ligamenta flava.

For the characterization, GAG preparations were separated by $2-\mathrm{D}-\mathrm{E}$ on cellulose acetate. Figure $2 \mathrm{a}$ shows Alcian blue-stained electrophoretogram of the GAG preparation of the residue from the calcified tissue. There appeared one major spot (chondroitin sulfate, CS) and two minor spots (hyaluronate, HA and dermatan sulfate, DS). Each GAG component was identified enzymatically as described previously (Oohira et al., 1986). Similar electrophoretograms were obtained both from the extract and from the residue of three different tissues. We also analyzed the uncalcified ligamenta flava from a patient with Coffin-Lowry syndrome aged 14 and normal ligamenta flava from a normal female aged 25, and it was observed that DS was a predominant composition of GAGs and the spot representing CS was hardly detected (Fig. 2b) in both control samples. From

Table 1. Characterization of ligamenta flava from three subjects.

\begin{tabular}{|c|c|c|c|c|c|}
\hline & \multicolumn{3}{|c|}{ Calcified ligamenta flava ${ }^{a}$} & \multirow{2}{*}{$\begin{array}{c}\text { Uncalcified } \\
\text { ligamenta } \\
\text { flavab }^{b}\end{array}$} & \multirow{2}{*}{$\underset{\text { flava }^{c}}{\text { Normal }}$} \\
\hline & $\begin{array}{l}\text { Calcified } \\
\text { center }\end{array}$ & $\begin{array}{l}\text { Transitional } \\
\text { area }\end{array}$ & $\begin{array}{l}\text { Peripheral } \\
\text { area }\end{array}$ & & \\
\hline \multicolumn{6}{|l|}{ Tissue weight (dry) } \\
\hline Acetone-dried (mg) & 68.5 & 125 & 1,070 & 18.7 & 60.9 \\
\hline Decalcified (mg) & 33.2 & 56.3 & 452 & & \\
\hline Total hexuronate $(\mu \mathrm{nol})$ & 1.45 & 1.47 & 2.82 & 0.114 & 0.262 \\
\hline Hexuronate in EDTA & 0.324 & 0.284 & 0.605 & & \\
\hline Hexuronate in residue & 1. 13 & 1. 19 & 2. 21 & & \\
\hline $\begin{array}{l}\text { Total hexuronate } \\
\text { (nmol/mg dry tissue) }\end{array}$ & 21.2 & 11.8 & 2.64 & 6. 10 & 4. 30 \\
\hline (Ratio to peripheral tissue) & $(8.0)$ & $(4.5)$ & (1) & $(2.3)$ & $(1.6)$ \\
\hline
\end{tabular}




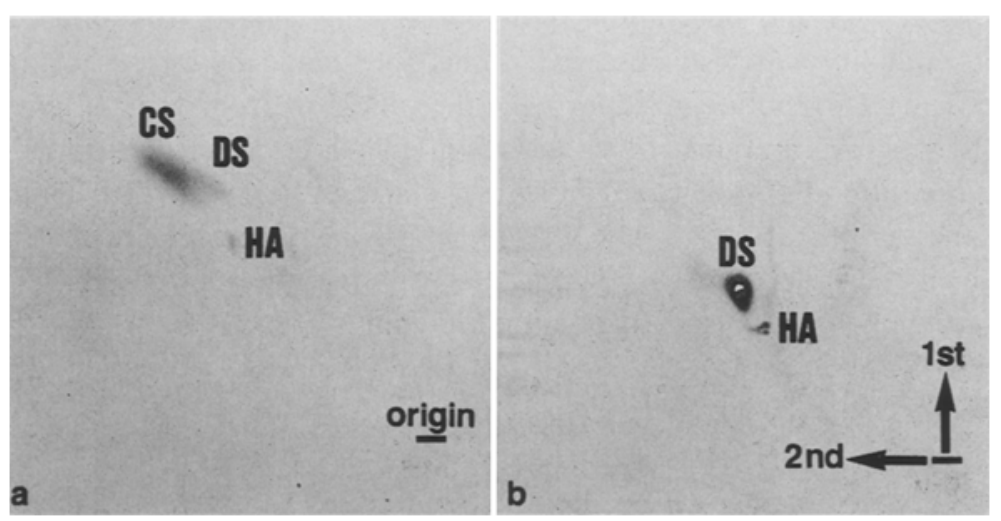

Fig. 2. GAG preparations from the residue of the calcified tissue (a) and from normal ligamenta flava (b) were separated by $2-\mathrm{D}-\mathrm{E}$ on cellulose acetate using $0.1 \mathrm{M}$ pyridine $/ 0.47 \mathrm{M}$ formic acid in the first dimension at a constant current of $1 \mathrm{~mA}$ per $\mathrm{cm}$ for $1 \mathrm{hr}$ and $0.1 \mathrm{M}$ barium acetate in the second dimension for $5 \mathrm{hr}$. Note that the major GAG in pathological ligamenta flava was CS. On the other hand, the major GAG in normal ligamenta flava was DS, and the spot representing CS was not evident.

Table 2. Relative amounts of chondroitin sulfate disaccharide units.

\begin{tabular}{lccc}
\hline & Calcified center & Transitional area & Peripheral area \\
\hline Disaccharide composition (\%) & & & \\
$\Delta$ Di-diS $^{\mathrm{a}}$ & 2.2 & 3.4 & 2.3 \\
$\Delta \mathrm{Di}-6 \mathrm{~S}^{\mathrm{b}}$ & 57.4 & 50.3 & 24.4 \\
$\Delta \mathrm{Di}^{-4 \mathrm{~S}^{\mathrm{c}}}$ & 24.1 & 34.5 & 45.0 \\
$\Delta \mathrm{Di}-0 \mathrm{~S}^{\mathrm{d}}$ & 5.0 & 6.5 & 1.8 \\
$\mathrm{DS}^{\mathrm{e}}$ & 11.3 & 5.3 & 26.5 \\
\hline
\end{tabular}

${ }^{2}$ A derivative of $\triangle \mathrm{Di}-0 \mathrm{~S}$ bearing sulfates at two different positions. b 2-Acetamido-2-deoxy-3- $O$ ( $\beta$-D-gluc-4-enepyranosyluronic acid)-6- $O$-sulfo-D-galactose. ${ }^{\mathrm{C}} 2$ 2-Acetamido-2-deoxy-3-O-( $\beta$-D-gluc4-enepyranosyluronic acid)-4- $O$-sulfo-D-galactose. d 2-Acetamido-2-deoxy-3- $O$-( $\beta$-D-gluc-4-enepyra nosyluronic acid)-D-galactose. ${ }^{-}$The composition of DS was calculated from the difference in the amounts of chondroitin sulfate disaccharide units formed by chondroitinase-ABC and -AC II.

these observations, it is concluded that the composition of GAGs in calcified ligamenta flava from an adult patient with Coffin-Lowry syndrome was abnormal.

To determine the relative amounts of chondroitin sulfate disaccharide units in GAGs prepared from each tissue, the GAG preparations from the residue and from the EDTA extract were combined. The combined preparation was digested either with chondroitinase-ABC or with chondroitinase-AC II. The unsaturated disaccharide products formed by chondroitinase digestion were separated by paper chromatography, and detected on paper chromatogram by viewing under ultraviolet light. In all samples examined, there appeared two major spots representing 
$\Delta \mathrm{Di}-6 \mathrm{~S}$ and $\triangle \mathrm{Di}-4 \mathrm{~S}$ and one minor spot representing $\Delta \mathrm{Di}-0 \mathrm{~S}$. Another faint spot with a less mobility was also observed. This spot could be an unsaturated disaccharide bearing two sulfate residues ( $\triangle \mathrm{Di}$-diS) judging from the mobility. Table 2 shows the relative amounts of chondroitin sulfate disaccharide units. It is obvious that the ratio of $\triangle \mathrm{Di}-6 \mathrm{~S}$ to $\Delta \mathrm{Di}-4 \mathrm{~S}$ was the highest in the calcified center and the lowest in the peripheral area. The amount of DS in the peripheral area was more than those in the other two tissues, and this observation may reflect the fact that the main component of normal ligamentum flavum is DS.

\section{DISCUSSION}

Cervical radiculomyelopathy due to spinal canal compression caused by calcified ligamenta flava is uncommon (Nakajima et al., 1984). Among reported cases, however, the affected patients were exclusively aged persons over 50 years and most of them were female (Nakajima et al., 1984). This is the first report of a patient with Coffin-Lowry syndrome with roentgenographically detectable calcified ligamenta flava. Computed tomography clearly showed that his cervical spinal canal was markedly narrowed, and his clinical pictures were in agreement with those of cervical radiculomyelopathy. Particular findings in this case were that the onset of calcifications was early, at least before 14 years old, and that the pathological lesions were far more extensive (C1-2 to C7-T1 and L2-3 to L4-5) than those of the aged persons. It has been suggested that motor function in patients with Coffin-Lowry syndrome deteriorate progressively (Temtamy et al., 1975). Cervical radiculomyelopathy caused by calcified ligamenta flava may be responsible for this deterioration. We also observed another two male adult patients with CoffinLowry syndrome with calcified ligamenta flava, and their clinical pictures will be reported elsewhere. Roentgenological evaluations of ligamenta flava should be necessary in patients with Coffin-Lowry syndrome.

Biochemical analysis of GAGs isolated from calcified ligamenta flava is noteworthy. Hexuronate content of the calcified center was significantly higher as compared with the peripheral area. Though the main component of GAGs in normal ligamenta flava is DS, CS was predominant in calcified ligamenta flava. It should be noteworthy that DS was the predominant GAG in uncalcified ligamenta flava from a young patient with Coffin-Lowry syndrome. Therefore, the amount of $\mathrm{CS}$ in calcified ligamenta flava from an adult patient with Coffin-Lowry syndrome is considered to have increased with the progress of calcifications. Additionally, the relative amount of chondroitin sulfate disaccharide units also seems to change with the progress of calcification, because there was a significant difference in the ratio of $\Delta \mathrm{Di}-6 \mathrm{~S}$ to $\Delta \mathrm{Di}-4 \mathrm{~S}$ between the calcified center and the peripheral area (Table 2). Since there have been no reports about the biochemical analysis of GAGs from calcified ligamenta flava in other diseases, it is unknown whether our findings are specific for Coffin-Lowry syndrome. However, proteoglycans play a role in calcification of cartilage matrix (Poole and Rosenberg, 1987), there is a possibility 
that the abnormal metabolism of GAGs is related to the calcifications in CoffinLowry patients. Our observations suggest that Coffin-Lowry syndrome is a connective tissue disease and that the metabolic abnormality of GAGs may be responsible for some aspects of this disease.

\section{REFERENCES}

Beck, M., Glössl, J., Rüter, R. and Kresse, H. 1983. Abnormal proteodermatan sulfate in three patients with Coffin-Lowry syndrome. Pediatr. Res. 17: 926-929.

Bitter, T. and Muir, H.M. 1962. A modified uronic acid carbazole reaction. Anal. Biochem. 4: $330-334$.

Coffin, G.S., Siris, E., Calif, E. and Wegienka, L.C. 1966. Mental retardation with osteocartilaginous anomalies. Am. J. Dis. Child. 112: 205-213.

Gorlin, R.J., Brown, D. and Sauk, J. 1978. Coffin-Lowry syndrome-a storage disorder? Birth Defects XIV(6B): 175.

Hata, R. and Nagai, Y. 1972. A rapid and micro method for separation of acidic glycosaminoglycans by two-dimensional electrophoresis. Anal. Biochem. 45: 462-468.

Lowry, B., Miller, J.R. and Fraser, F.C. 1971. A new dominant gene mental retardation syndrome. Association with small stature, tapering fingers, characteristic facies, and possible hydrocephalus. Am. J. Dis. Child. 121: 496-500.

Nakajima, K., Miyaoka, M., Sumie, H., Nakazato, T. and Ishii, S. 1984. Cervical radiculomyelopathy due to calcification of the ligamenta flava. Surg. Neurol. $21: 479-488$.

Oohira, A., Matsui, F., Matsuda, M. and Shoji, R. 1986. Developmental change in the glycosaminoglycan composition of the rat brain. J. Neurochem. 47: 588-593.

Poole, A.R. and Rosenberg, L.C. 1987. Proteoglycans, chondrocalcin, and the calcification of cartilage matrix in endochondrial ossification. In Biology of Proteoglycans. Wight, T.N. and Mecham, R.P., eds., Academic Press, Orlando, pp. 187-210.

Saito, H., Yamagata, T. and Suzuki, S. 1968. Enzymatic methods for the determination of small quantities of isomeric chondroitin sulfates. J. Biol. Chem. 243: 1536-1542.

Temtamy, S.A., Miller, J.D., Dorst, J.P., Hussels-Maumenee, I., Salinas, C., Lacassie, Y. and Kenyon, K.R. 1975. The Coffin-Lowry syndrome: a simply inherited trait comprising mental retardation, faciodigital anomalies and skeletal involvement. Birth Defects XI(6): 133-152. 